\title{
ZAKAT PROFESI
}

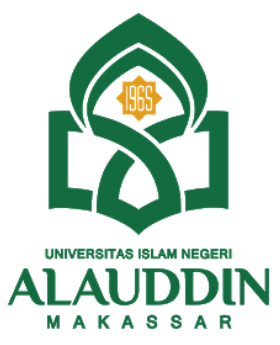

MAKALAH

Disusun Untuk Memenuhi Tugas Mata Kuliah Manajemen Zakat dan Wakaf(ZIZWAF) Program Studi Perbankan Syariah Semester V Tahun 2021

Oleh :

Fadiah Salsabila

Nim : 90500119070

Perbankan Syariah C

Dosen Pengajar :

SUPRIADI, S.E.I.,M.E.I

PROGRAM STUDI PERBANKAN SYARIAH

FAKULTAS EKONOMI DAN BISNIS ISLAM UIN ALAUDDIN MAKASSAR

2021/2022 


\section{KATA PENGANTAR}

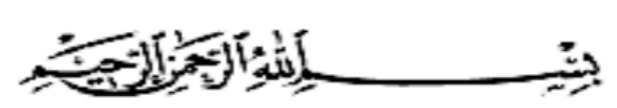

Puji syukur kehadirat Allah SWT. yang telah memberikan segala berkah, taufiq dan bimbingannya untuk menyelesaikan tugas makalah yang berjudul "Zakat Profesi”.

Shalawat dan salam kepada junjungan kita Nabi Muhammad SAW tercinta, yang memimpin kita dari zaman kegelapan ke zaman terang.

Penyusun berharap makalah ini dapat membantu pembaca memahami dan mempelajari lebih lanjut tentang zakat profesi. Sebagai penulis, saya memahami bahwa masih banyak kesalahan dan kekurangan dalam penulisan makalah ini. Oleh karena itu, sebagai penyusun kami mengharapkan dan menerima segala bentuk saran dan kritik dari para pembaca semoga bermanfaat dalam memperbaiki dan memajukan makalahmakalah selanjutnya.

Makassar, 23 November 2021

Fadiah Salsabila 


\section{DAFTAR ISI}

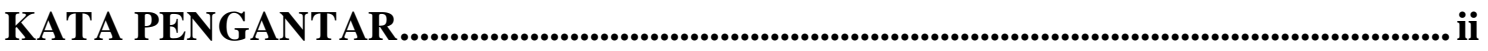

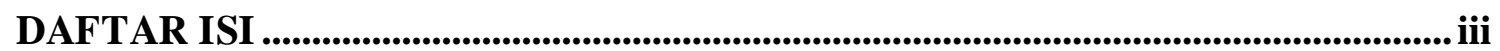

\section{BAB I}

PENDAHULUAN

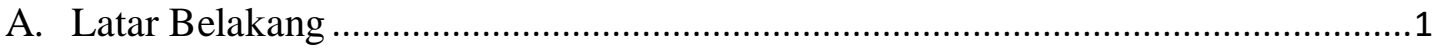

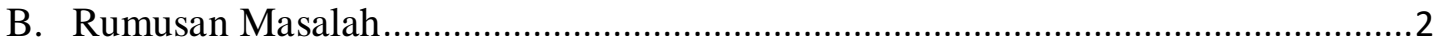

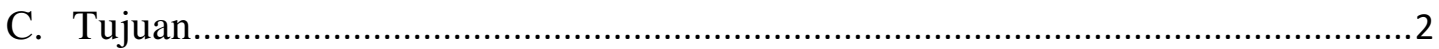

\section{BAB II}

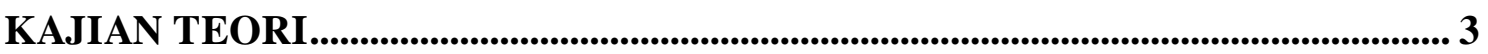

A. Definisi Zakat...........................................................

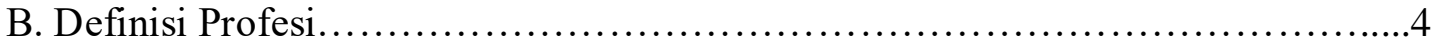

C. Definisi Zakat Profesi......................................................4

\section{BAB III}

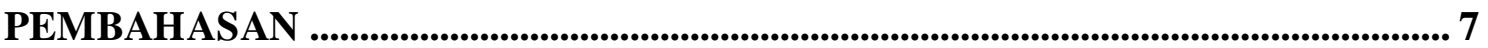

A. Sejarah Zakat Profesi......................................................... 7

B. Dasar Hukum Zakat Profesi.....................................................

C. Zakat Profesi dalam Perspektif UU No.23 Tahun $2011 \ldots \ldots \ldots \ldots \ldots \ldots \ldots \ldots \ldots$

D. Nisab Zakat Profesi dan Cara Menghitungnya..............................11

\section{BAB IV}

PENUTUP

A. Kesimpulan............................................................. 14

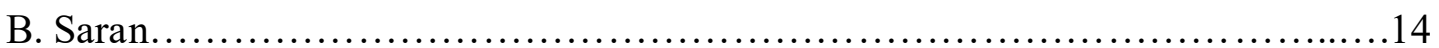

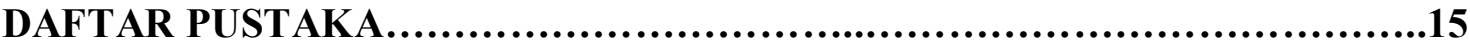




\section{BAB I \\ PENDAHULUAN}

\section{A. Latar Belakang}

Istilah zakat profesi dipopulerkan oleh Yusuf al-Qaradhawi (1969) dalam Kitab Fiqh al-Zakâh dengan penggunakan kata kasb al-amal wa al-mihn al-hurrah yang dapat diartikan dengan pencarian dan profesi, yaitu berbagai usaha yang menghasilkan harta kekayaan berupa uang dan sebagainya. Usaha atau kegiatan tersebut dilakukan dengan kemampuan fisik, keterampilan tangan atau kemampuan otak termasuk jasa dan usahausaha dari seseorang atau sekelompok orang. Wahbah al-Zuhayli (1997: III/1948) secara khusus mengemukakan kegiatan profesi atau pendapatan yang diterima seseorang melalui usaha sendiri seperti dokter, insinyur, ahli hukum, penjahit dan lain sebagainya. Adapun yang terkait dengan pemerintah (pegawai negeri) atau pegawai swasta yang mendapatkan gaji atau upah dalam waktu yang relative tetap, seperti sebulan sekali. Pendapatan semacam ini dalam istilah fiqh dikatakan sebagai al-Mâl alMustafad (harta yang dimanfaatkan oleh seorang muslim dan dimilikinya sebagai kepemilikan baru yang didapatkan dengan cara apapun asal sesuai syariat, misalnya bekerja yang akhirnya mendapatkan penghasilan/upah dan profesi). Dalam Al-Mujam al-Wasît (1972) istilah zakat profesi menggunakan kata "zakâh al-mihnah" (zaka on income) berarti zakat atas penghasilan atau pendapatan atau jasa yang dusahakan melalui keahliannya, seperti profesi dokter, arsitek, ahli hukum, pengacara, pegawai, karyawan dan lain-lain.

Zakat profesi yang dikumpulkan dapat didistribusikan kepada para mustahik dalam mewujudkan kesejahteraan umat. A. Zysow (2001) menjelaskan hukum zakat dapat disebut sebagai hibrida antara unsur ibadah dan peningkatan penghasilan. Banyak orang yang yakin bahwa zakat jika dikelola dengan baik dapat membantu negara dalam menghadapi krisis keuangan dan menyejahterakan rakyatnya. Hal itu tidak berarti zakat yang dikumpulkan oleh negara digunakan untuk membiyai negara, tetapi sebaliknya 
negara hanya berperan sebagai fasilitator dalam mengumpulkan zakat, yang dalam hal ini bertindak sebagai amil zakat. ${ }^{1}$

\section{B. Rumusan Masalah}

1. Bagaimana sejarah zakat profesi?

2. Bagaimana dasar hukum zakat profesi dalam Islam?

3. Bagaimana zakat profesi dalam perspektif UU No.23 Tahun 2011?

4. Bagaimana nisab zakat profesi dan cara perhitungannya?

\section{Tujuan}

1. Untuk mengetahui sejarah zakat profesi.

2. Untuk memahami dasar hukum zakat profesi dalam Islam.

3. Untuk memahami zakat profesi dalam perspektif UU No.23 Tahun 2011.

4. Untuk mengetahui dan memahami nisab zakat profesi dan cara perhitungannya.

${ }^{1}$ Muhammad Zen, 'Zakat Profesi Sebagai Distribusi Pendapatan Ekonomi Islam', Human Falah, 1.1 (2014), 63-91. 


\section{BAB II}

\section{KAJIAN TEORI}

\section{A. Definisi Zakat}

Definisi zakat Ditinjau dari segi bahasa kata zakat merupakan kata dasar dari zakaa yang berarti suci, berkah, tumbuh dan terpuji. Sedangkan dari segi istilah fiqh, zakat berarti sejumlah harta tertentu yang diwajibkan Allah diserahkan kepada orang yang berhak menerimanya, disamping berarti mengeluarkan jumlah tertentu itu sendiri.

Secara terminologi zakat adalah sejumlah harta yang diwajibkan oleh Allah diambil dari harta orang-orang tertentu (aghniyā') untuk diberikan kepada orang-orang yang berhak menerimanya dengan syarat-syarat tertentu. Zakat adalah salah satu rukun Islam yang berdimensi keadilan sosial kemasyarakatan. Esensi dari zakat adalah pengelolaan dana yang diambil dari aghniyā' (QS. al-Taubah [9]: 103), untuk diserahkan kepada yang berhak menerimanya (QS. al-Taubah [9]: 60) dan bertujuan untuk mensejahterakan kehidupan sosial kemasyarakatan umat Islam (QS. al-Dzariyat [51]: 19). Hal tersebut setidaknya tercermin dari firman-firman Allah yang berkaitan dengan perintah zakat.

Selain itu, diperkuat pula dengan perintah Nabi Muhammad SAW kepada Mu'adz bin Jabal yang diperintahkan untuk mengambil dan mengumpulkan harta (zakat) dari orang-orang kaya yang kemudian dikembalikan kepada fakir miskin dari kelompok mereka. Dalam istilah ekonomi, zakat merupakan suatu tindakan pemindahan harta kekayaan dari golongan yang kaya kepada golongan miskin. Transfer kekayaan berarti juga transfer sumber-sumber ekonomi. Rahardjo (1987) menyatakan bahwa dengan menggunakan pendekatan ekonomi, zakat bisa berkembang menjadi konsep kemasyarakatan (muamalah), yaitu konsep tentang bagaimana cara manusia melakukan kehidupan bermasyarakat termasuk di dalamnya bentuk ekonomi. Oleh karena itu ada dua konsep ada dua konsep yang selalu di kemukakan dalam pembahasan mengenai sosial ekonomi Islam yang saling berkaitan yaitu pelarangan riba dan perintah membayar zakat (Q.S al-Baqarah [2]: 276) Zakat ditinjau dari pendekatan etnis dan pemikiran rasional ekonomis adalah sebagai kebijaksanaan ekonomi yang dapat mengangkat derajat orang-orang miskin, sehingga dampak sosial yang diharapkan dapat 
tercapai secara maksimal. Hal ini dapat terwujud apabila dilakukan pendistribusian kekayaan yang adil. Zakat mungkin didistribusikan secara langsung kepada orang-orang yang berhak, baik kepada satu atau lebih penerima zakat maupun kepada organisasi sosial yang mengurusi fakir miskin. Namun hendaknya dialokasikan orang-orang yang benar membutuhkan. Untuk menghindari pemberian zakat kepada orang yang salah, maka pembayar zakat hendaknya memastikan dulu. ${ }^{2}$

\section{B. Definisi Profesi}

Dalam KBBI, profesi adalah bidang pekerjaan yang dilandasi pendidikan keahlian (keterampilan, kejuruan, dan sebagainya) tertentu. Kata Profesi sendiri berasal dari bahasa latin "Proffesio" yang mempunyai dua definisi yaitu janji/ikrar dan pekerjaan. Bila artinya dibuat dalam definisi yang lebih luas menjadi kegiatan "apa saja" dan "siapa saja" untuk memperoleh nafkah yang dilakukan dengan suatu keahlian tertentu. Sedangkan dalam arti sempit profesi berarti kegiatan yang dijalankan berdasarkan keahlian tertentu dan sekaligus dituntut daripadanya pelaksanaan normanorma sosial dengan baik.

Profesi secara istilah berarti suatu pekerjaan yang membutuhkan pengetahuan, keahlian, dan kepintaran. Yusuf al-Qardhawi lebih jelas mengemukakan bahwa profesi adalah pekerjaan atau usaha yang menghasilkan uang atau kekayaan baik pekerjaan atau usaha itu dilakukan sendiri, tanpa bergantung kepada orang lain, maupun dengan bergantung kepada orang lain, seperti pemerintah, perusahaan swasta, maupun dengan perorangan dengan memperoleh upah, gaji, atau honorium. Penghasilan yang diperoleh dari kerja sendiri itu, merupakan penghasilan proesional murni, seperti penghasilan seorang dokter, insinyur, deseiner, advokat, seniman, penjahit, tenaga pengajar (guru, dosen, dan guru besar), konsultan, dan sejenisnya. Adapun hasil yang diperoleh dari pekerjaan yang dilakukan dengan pihak lain adalah jenis-jenis pekerjaan seperti pegawai, buruh, dan sejenisnya. Hasil kerja ini meliputi upah dan gaji atau penghasilanpenghasilan tetap lainnya yang mempunyai nisab.

\section{Definisi Zakat Profesi}

${ }^{2}$ Fuad Riyadi, 'Kontroversi Zakat Profesi Pesrpektif Ulama Kontemporer', Jurnal Zakat Dan Wakaf, 2.1 (2015), 110-12. 
Zakat profesi tergolong jenis baru dalam kategorisasi harta yang wajib dikeluarkan zakatnya. Istilah profesi dalam terminologi Arab tidak ditemukan padanan katanya secara eksplisit. Hal ini terjadi karena bahasa Arab adalah bahasa yang sangat sedikit menyerap bahasa asing. Di negara Arab modern, istilah profesi diterjemahkan dan dipopulerkan dengan dua kosakata bahasa Arab. Pertama, a 1- mihnah. Kata ini sering dipakai untuk menunjuk pekerjaanyang lebih mengandalkan kinerja otak. Karena itu, kaum profesional disebut al-mihaniyyun atau ashab al-mihnah. Misalnya, pengacara, penulis, dokter, konsultan hukum, pekerja kantoran, dan lain sebagainya. Kedua, al-hirfah. Kata ini lebih sering dipakai untuk menunjuk jenis pekerjaan yang mengandalkan tangan atau tenaga otot. Misalnya, para pengrajin, tukang pandai besi, tukang jahit pada konveksi, buruh bangunan, dan lain sebagainya. Mereka disebut ashab al-hirfah. $^{3}$

Zakat profesi terdiri dari dua kata yaitu zakat dan profesi. Dalam literatur fiqh klasik pengertian zakat adalah hak yang dikeluarkan dari harta atau badan. Sehubungan dengan hal ini, Wahbah al-Zuhayly mengemukakan bahwa zakat adalah penuanaian hak yang wajib yang terdapat dalam harta. Dalam kamus Bahasa Indonesia, profesi adalah bidang pekerjaan yang dilandasi pendidikan keahlian (keterampilan, kejujuran, dan sebagainya) tertentu. Zakat profesi adalah zakat yang di keluarkan dari hasil apa yang di peroleh dari pekerjaan dan profesinya. Misalnya pekerjaan yang menghasilkan uang baik itu pekerjaan yang dikerjakan sendiri tampa tergantung dengan orang lain, berkat kecekatan tangan ataupun otak (professional). Maupun pekerjaan yang dikerjakan seseorang buat pihak lain baik pemerintah, perusahaan, maupun perorangan dengan memperoleh upah yang diberikan, dengan tangan, otak, ataupun keduanya. Penghasilan dari pekerjaan seperti itu berupa gaji, upah, ataupun honorarium. Yang demikian itu apabila sudah mencapai nisabnya dan haulnya pendapatan yang ia hasilkan harus di keluarkan zakatnya.

Menurut Wikipedia, zakat profesi adalah zakat yang dikeluarkan dari penghasilan profesi ( guru, dokter, aparat, dan lain-lain ) atau hasil profesi bila telah sampai pada nisabnya. Berbeda dengan sumber pendapatan dari pertanian, peternakan dan perdagangan, sumber pendapatan dari profesi tidak banyak dikenal di masa generasi terdahulu.

${ }^{3}$ Deny Setiawan, 'ZAKAT PROFESI DALAM PANDANGAN ISLAM', JURNAL SOSIAL EKONOMI PEMBANGUNAN, 1.2 (2011), 195-208. 
Dalam pandangan al-Ghazali zakat merupakan jenis ibadah yang berbentuk ritual sekaligus material tidak seperti ibadah syahadat, shalat atau puasa. Untuk bisa sampai ke arah sana diperlukan pemahaman yang memadai untuk menyadarkan bahwa kewajiban zakat bukanlah sekedar amaliah ritual mahdhah saja, tetapi juga memiliki makna kewajiban sosial. Zakat adalah kesalehan diri melalui ikhtiar sosial. Agar sampai kepada kesadaran seperti itu diperlukan penyadaran yang dibarengi dengan tindakan amal-amal sosial, termasuk mengeluarkan zakat, infak dan shadaqah. Karena dalam ajaran zakat ini pandangan dan komitmen sosialnya begitu jelas, bahkan dari titik kepentingan yang paling menyentuh hajat orang banyak, yaitu pemenuhan kebutuhan ekonomi.

Secara umum zakat profesi menurut putusan Tarjih Muhammadiyah adalah zakat yang dikeluarkan dari hasil usaha yang halal yang dapat mendatangkan hasil atau uang, relatif banyak dengan cara yang halal dan mudah, baik melalui keahlian tertentu maupun tidak. Sedangkan dalam pemahaman Zamzami Ahmad, zakat profesi adalah zakat penghasilan yang didapat dan diterima dengan jalan yang halal dalam bentuk upah, honor ataupun gaji. ${ }^{4}$

${ }^{4}$ Agus dan Tira Nur Fitria Marimin, 'Zakat Profesi (Zakat Penghasilan) Menurut Hukum Islam', Jurnal Ilmiah Ekonomi Islam, 01.01 (2015), 50-60. 


\section{BAB III \\ PEMBAHASAN}

\section{A. Sejarah Zakat Profesi}

Zakat profesi tidak pernah ada dalam sepanjang sejarah Islam sejak masa Rasulullah SAW hingga tahun 60-an akhir pada abad ke-20 yang lalu, ketika mulai muncul gagasan zakat profesi ini. Penggagas zakat profesi adalah Syeikh Yusuf Qardhawi dalam kitabnya Fiqh Az Zakah, yang cetakan pertamanya terbit tahun 1969. Namun nampaknya Yusuf Qardhawi dalam hal ini mendapat pengaruh dari dua ulama lainnya, yaitu Syeikh Abdul Wahhab Khallaf dan Syeikh Abu Zahrah. Kajian dan praktik zakat profesi mulai marak di Indonesia kira-kira sejak tahun 90-an akhir dan awal tahun 2000-an. Khususnya setelah kitab Yusuf Qardhawi tersebut diterjemahkan ke dalam bahasa Indonesia oleh Didin Hafidhuddin dengan judul Fikih Zakat yang terbit tahun 1999. Sejak saat itu zakat profesi mulai banyak diterapkan oleh lembaga pengelola zakat di Indonesia, baik BAZ (badan amil zakat) milik pemerintah, baik BASDA atau BASNAZ, maupun LAZ (lembaga amil zakat) milik swasta, seperti PKPU, Dompet Dhuafa, dan sebagainya.

\section{B. Dasar Hukum Zakat Profesi}

1. Al-Qur'an

Nash-nash yang dijadikan landasan dalam hukum zakat diantaranya:

a. QS. Al A'la: 14-15

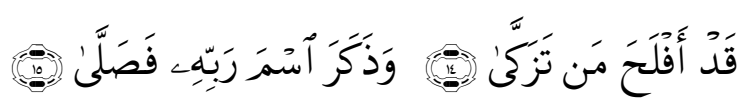

Artinya: "Sesungguhnya beruntunglah orang yang membersihkan diri (dengan beriman) dan dia ingat nama Tuhannya, lalu dia sembahyang"

b. QS. At Taubah: 34-35

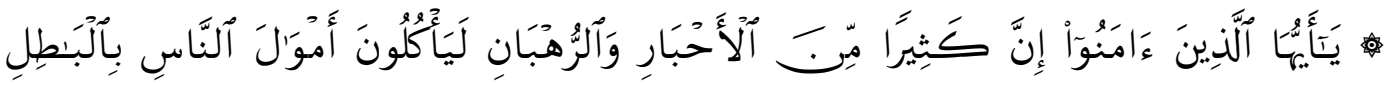

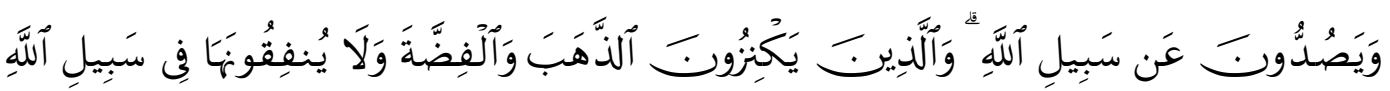




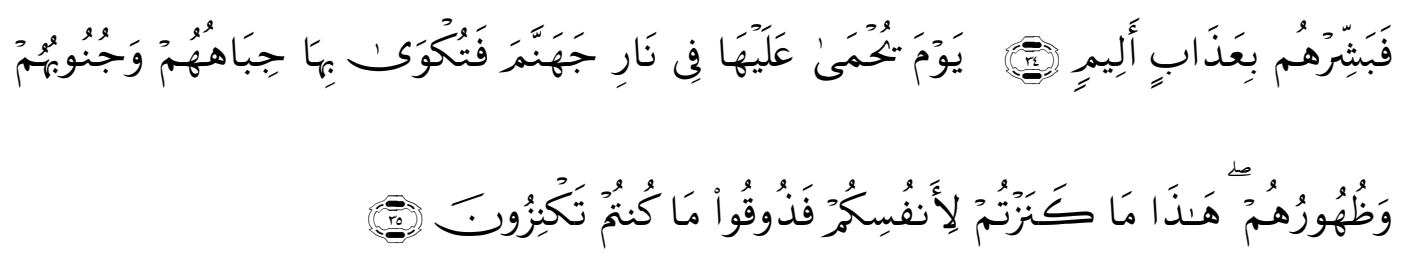

Artinya: "Hai orang-orang yang beriman, sesungguhnya sebahagian besar dari orangorang alim Yahudi dan rahib-rahib Nasrani benar-benar memakan harta orang dengan jalan batil dan mereka menghalang-halangi (manusia) dari jalan Allah. Dan orang-orang yang menyimpan emas dan perak dan tidak menafkahkannya pada jalan Allah, maka beritahukanlah kepada mereka, (bahwa mereka akan mendapat) siksa yang pedih. Pada hari dipanaskan emas perak itu dalam neraka jahannam, lalu dibakar dengannya dahi mereka, lambung dan punggung mereka (lalu dikatakan) kepada mereka: "Inilah harta bendamu yang kamu simpan untuk dirimu sendiri, maka rasakanlah sekarang (akibat dari) apa yang kamu simpan itu"

c. Q.S At-Taubah ayat 103

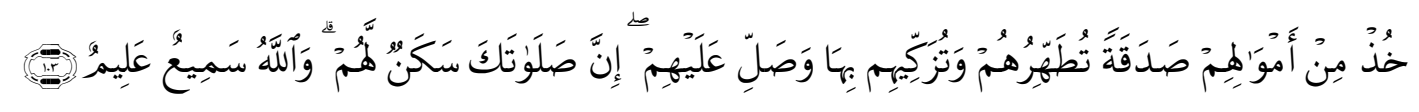

Artinya: "Ambillah zakat dari sebagian harta mereka, dengan zakat itu kamu membersihkan dan mensucikan mereka dan berdoalah untuk mereka. Sesungguhnya doa kamu itu (menjadi) ketentraman jiwa bagi mereka. Dan Allah maha mendengar lagi maha mengetahui".

Ayat di atas menerangkan tentang siksaan yang diberikan kepada orang-orang yang menyimpan harta tapi tidak mau menafkahkannya pada jalan Allah (berzakat). Dengan demikian ayat ini juga menunjukkan bahwa zakat harta atau zakat mal itu wajib hukumnya. Juga hadits riwayat muttafaqun alaihi yang artinya: "Islam didirikan diatas lima dasar: Mengikrarkan bahwa tidak ada tuhan selain Alloh dan Muhammad adalah utusan Alloh, mendirikan sholat, membayar zakat, menunaikan haji, dan berpuasa pada bulan Romadhon". (H.R. Muttafaq 'alaih)

d. QS. At Taubah: 60 


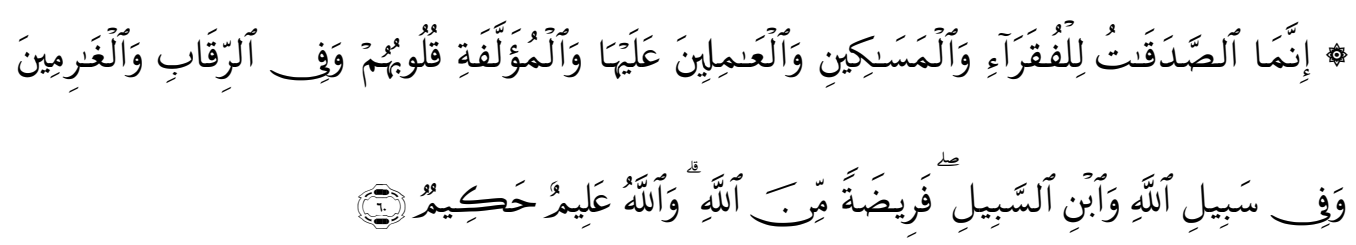

Artinya: "Sesungguhnya zakat-zakat itu, hanyalah untuk orang-orang fakir, orang-orang miskin, pengurus-pengurus zakat, para mu allaf yang dibujuk hatinya, untuk (memerdekakan) budak, orang-orang yang berhutang, untuk jalan Allah dan untuk mereka yuang sedang dalam perjalanan, sebagai suatu ketetapan yang diwajibkan Allah, dan Allah Maha Mengetahui lagi Maha Bijaksana”.

2. Hadist

a. HR Bukhari Muslim

$$
\begin{aligned}
& \text { من عا صا ال ناس ع لى رمضان من ال فر زكاة م.ص.ص هلالار سول ف رض ق ال عمر اب ن عن }
\end{aligned}
$$

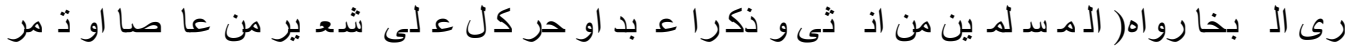

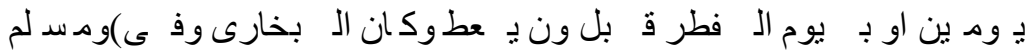

Artinya: "Dari Ibn Umar ia berkata: Rasulullah saw mewajibkan zakat fitri (berbuka) bulan ramadhan sebanyak satu sha' (3,1 liter) kurma atau gandum atas tiap-tiap orang muslim merdeka atau hamba, laki-laki atau perempuan"

Dalam hadis Bukhari disebutkan "mereka membayar fitrah itu sehari atau dua hari sebelum hari raya"

b. HR Abu Dawud dan Ibn Majah

$$
\begin{aligned}
& \text { لـ لد ساطعة و دُ مل لـصاطهرة الـ فطر زكاة .م.ص هللار سول ف رض :ق ال ع باس اب ن عن }
\end{aligned}
$$

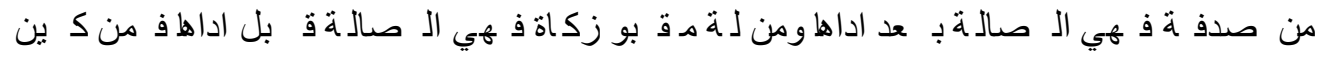

$$
\begin{aligned}
& \text { الـ الـ صدف ات }
\end{aligned}
$$

Artinya:"Dari Ibn Abbas, ia berkata: telah diwajibkan oleh rasulullah saw zakat fitrah sebagai pembersih bagi orang puasa dan memberi makan bagi orang miskin, barang siapa yang menunaikannya sebelum sholat hari raya maka zakat itu diterima, dan barang siapa membayarnya sesudah sholat hari raya maka zakat itu sebagai sedekah biasa",5

\section{Zakat Profesi dalam Perspektif UU No. 23 Tahun 2011}

5 Elpianti Sahara Pakpahan, 'PANDANGAN ULAMA TENTANG ZAKAT PROFESI', $A L$ HADI, III.2 (2018), 629-37. 
Undang-Undang No. 23 Tahun 2011, merupakan bentuk perundangundangan tertinggi yang mengatur ketentuan pengelolaan zakat di Indonesia, yang sebelumnya diatur oleh Undang-Undang No. 38 Tahun 1999 tentang Pengelolaan Zakat. Walaupun UU No 23 Tahun 2011 ini pernah digugat ke Mahkamah Konstitusi oleh sebagian kelompok pegiat LAZ pada tahun 2012, akan tetapi eksistensi dari undang-undang tersebut tetap mengikat dan tetap berlaku, kecuali 3 pasal yang telah dibatalkan oleh Mahkamah Konstitusi, yaitu pasal yaitu; pasal 18 ayat 02 (huruf a, b dan d) serta pasal 38 dan pasal 41.

Adapun poin-poin penting yang menjadi materi UU No 23 Tahun 2011 tersebut antara lain, tentang asas pengelolaan zakat, tujuan pengelolaan zakat dan lain lain. Tentang asas pengelolaan zakat disebutkan dalam pasal 2 UU No. 23 Tahun 2011 menyatakan bahwa:

Pengelolaan zakat berasaskan:
a. syariat Islam;
b. amanah;
c. kemanfaatan;
d. keadilan;
e. kepastian hukum;
f. terintegrasi; dan
g. akuntabilitas

Adapun pasal terkait dengan tujuan pengelolaan zakat, disebutkan dalam pasal 3 UU No. 23 Tahun 2011 menyatakan:

Pengelolaan zakat bertujuan:

a. meningkatkan efektivitas dan efisiensi pelayanan dalam pengelolaan zakat; dan

b. meningkatkan manfaat zakat untuk mewujudkan kesejahteraan masyarakat dan penanggulangan kemiskinan.

Selain itu, salah satu isi dan materi dari UU No 23 Tahun 2011 tersebut yang menarik lagi untuk dilihat lebih jeli, adalah keberadaan zakat profesi yang termuat dalam pasal 4 ayat (2) bagian (h), yaitu:

(1) Zakat meliputi zakat mal dan zakat fitrah.

(2) Zakat mal sebagaimana dimaksud pada ayat (1) meliputi:

a) emas, perak, dan logam mulia lainnya; 
b) uang dan surat berharga lainnya;

c) perniagaan;

d) pertanian, perkebunan, dan kehutanan;

e) peternakan dan perikanan

f) pertambangan;

g) perindustrian;

h) pendapatan dan jasa; dan

i) rikaz

Memang secara eksplisit tidak disebutkan istilah profesi dalam pasal tersebut, akan tetapi dalam kolom (h) pasal 4 ayat (2) tersebut disebutkan bahwa diantara bentuk zakat mal adalah pendapatan dan jasa, ini artinya memberikan peluang terhadap bentuk aktifitas-aktfitas dan jasa yang menghasilkan pendapatan materi. Pada tahap inilah kemudian bermakna, bahwa setiap profesi yang menghasilkan pendapatan materi harus dikeluarkan zakatnya. Berdasarkan uraian tersebut di atas, menurut penulis bahwa setiap keahlian dan pekerjaan apapun yang halal, baik yang dilakukan sendiri maupun yang berkaitan dengan pihak lain, seperti seorang pegawai maupun karyawan, apabila penghasilan dan pendapatannya mencapai nishab, maka wajib dikeluarkan zakatnya. ${ }^{6}$

\section{Nisab Zakat Profesi dan Cara Perhitungannya}

Nisab merupakan batas minimal atau jumlah minimal harta yang dikenai kewajiban zakat. Karena zakat profesi ini tergolong baru, nisabnya pun mesti dikembalikan (dikiaskan) kepada nishab zakat-zakat yang lain, yang sudah ada ketentuan hukumnya.

Ada dua kemungkinan yang dapat dikemukakan untuk ukuran nishab zakat profesi ini.

1. Disamakan dengan nishab zakat emas dan perak, yaitu dengan mengkiaskannya kepada emas dan perak sebagai standar nilai uang yang wajib dikeluarkan zakatnya, yakni 20 dinar atau 93,6 gram emas. Berdasarkan Hadis RiwayatDaud: (Tidak ada suatu kewajiban bagimu-dari emas (yang engkau miliki) hingga mencapai jumlah 20 dinar)

${ }^{6}$ Muhammad Aziz dan Sholikah, 'UNDANG-UNDANG NO . 23 TAHUN 2011 DAN HUKUM ISLAM’, Ulul Albab, 15.2 (2014), 188-205. 
2. Disamakan dengan zakat hasil pertanian yaitu 5 wasq (sekitar $750 \mathrm{~kg}$ beras). Zakatnya dikeluarkan pada saat diterimanya penghasilan dari profesi tersebut sejumlah 5 atau $10 \%$, sesuai dengan biaya yangdikeluarkan.

Karena profesi itu sendiri bermacam-macam bentuk, jenis dan perolehan uangnya, penulis cenderung untuk tetap memakai kedua macam standar nisab zakat tersebut dalam menentukan nishab zakat profesi, dengan perimbangan sebagai berikut.

Pertama, untuk jenis-jenis profesi berupa bayaran atas keahlian, seperti dokter spesialis, akuntan, advokat, kontraktor, arsitek, dan profesiprofesi yang sejenis dengan itu, termasuk juga pejabat tinggi negara, guru besar, dan yang sejajar dengannya, nishab zakatnya disamakan dengan zakat hasil pertanian, yakni senilai kurang lebih $750 \mathrm{~kg}$ beras ( 5 wasaq). Meskipun kelihatannya pekerjaan tersebut bukan usaha yang memakai modal, namun ia sebenarnya tetap memakai modal, yaitu untuk peralatan kerja, transportasi, sarana kominikasi seperti telephon, rekening listrik, dan lain-lain, zakatnya dikiaskan atau disamakan dengan zakat hasil pertanian yang memakai modal, yakni 5 $\%$, dan dikeluarkan ketika menerima bayaran tersebut. Ini sama dengan zakat pertanian yang yang menggunakan biaya irigasi (bukan tadahhujan).

Dengan demikian, jika harga beras 1 kg Rp. 3200, sedangkan nisab (batas minimal wajib zakat) tanaman adalah $750 \mathrm{~kg}$, maka untuk penghasilan yang mencapai Rp. 3.200 x $750=$ Rp. 2.400.000., wajib mengeluarkan zakatnya sebanyak 5\% nya yakni Rp. 120.000.-

Pendapat semacam ini sesuai dengan pendapat Muhammad Ghazali, sebagaimana yang dikutip Yusuf Qardawi, bahwa dasar dan ukuran zakat penghasilan tanpa melihat modalnya, dapat disamakan dengan zakat pertanian yaitu 5 atau 10 persen. Kata Ghazali, siapa yang memiliki pendapatan tidak kurang dari pendapatan seorang petani, terkena kewajiban zakat. Maka gologan profesionalis wajib mengeluarkan zakatnya sebesar zakat petani tersebut, tanpa mempertimbangkan keadaan modal dan persyaratan lainnya.

Seperti ini pula yang ditetapkan oleh Kamar Dagang dan Industri kerajaan Arab Saudi, bahwa penghasilan profesi yang bukan bersifat perdagangan, dikiaskan nisab zakatnya kepada zakat hasil tanam-tanaman dan buah- buahan dengan kadar zakat ssebesar 5\%. 
Tawaran seperti ini lebih kecil dari yang diusulkan oleh M. Amin Rais, dalam bukunya Cakrawala Islam Antara Cita dan Fakta. Menurutnya profesi yang mendatangkan rizki dengan gampang dan cukup melimpah, setidaknya jika dibandingkan dengan penghasilan rata-rata penduduk, sebaiknya zakatnya ditingkatkan menjadi 10 persen (usyur) atau 20 persen (khumus). Lebih jauh Amin mempersoalkan masih layakkah, profesi-profesi moderen seperti dokter spesialis, komisaris perusahaan, bankir, konsultan, analis, broker, pemborong berbagai konstruksi, eksportir, inportir, notaris, artis, dan berbagai penjual jasa serta macam-macam profesi kantoran (white collar) lainnya, hanya mengeluarkan zakat sebesar 2,5 persen, dan lebih kecil dari petani kecil yang zakat penghasilannya berkisar sekitar 5 sampai 10 persen. Padahal kerja tani jela smerupakan pekerjaan yang setidaktidaknya secara fisik. Cukupkah atau sesuaikan dengan spirit keadilan Islam jika zakat terhadap berbagai profesi moderen yang bersifat making-money tetap 2,5 persen? Layakkah presentasi sekecil itu dikenakan terhadap profesi-profesi yang pada zaman Nabi memang belum ada.

Hemat penulis, pendapat Amin Rais di atas sebenarnya cukup logis dan cukup argumentatif, namun membandingkan profesi dengan rikaz (barang temuan) agaknya kurang tepat. Rikaz diperoleh dengan tanpa usaha sama sekali, sementara profesi membutuhkan usaha dan keahlian serta biaya yang kadang- kadang cukup tinggi. Karena itu penulis cenderung untuk menyamakanya dengan zakat pertanian yang memakai biaya irigasi, yakni 5 persen.

Kedua, Bagi kalangan profesional yang bekerja untuk pemerintah misalnya, atau badan-badan swasta yang gajinya tidak mencapai nishab pertanian sebagaimana yang dikemukakan di atas, sebutlah guru misalnya, atau dokter yang bekerja di rumah sakit, atau orang-orang yang bekerja untuk suatu perusahaan angkutan. Zakatnya disamakan dengan zakat emas dan perak yakni 93,6 gram (sekitar Rp. 8.424.000, jika diperkirakan harga pergram emas sekarang 90.000,) maka nilai nishab emas adalah Rp. Rp. 8.424.000, dengan kadar zakat 2,5 \%. Jika pada akhir tahun jumlah mencapai satu nisab, dikeluarkan zakatnya 2,5 persen, setelah dikeluarkan biaya pokok dari yang bersangkutan dan keluarganya. ${ }^{7}$

${ }^{7}$ Ikbal Baidowi, 'ZAKAT PROFESI (ZAKAT PENGHASILAN)', TAZKIYA Jurnal Keislaman, Kemasyarakatan \& Kebudayaan, 19.1 (2018), 40-54. 


\section{BAB IV \\ PENUTUP}

\section{A. Kesimpulan}

Dari beberapa penjelasan yang sudah dipaparkan, maka dapat disimpulkan bahwa :

1. Zakat profesi adalah zakat yang di keluarkan dari hasil apa yang di peroleh dari pekerjaan dan profesinya. Misalnya pekerjaan yang menghasilkan uang baik itu pekerjaan yang dikerjakan sendiri tampa tergantung dengan orang lain, berkat kecekatan tangan ataupun otak (professional). Maupun pekerjaan yang dikerjakan seseorang buat pihak lain baik pemerintah, perusahaan, maupun perorangan dengan memperoleh upah yang diberikan, dengan tangan, otak, ataupun keduanya. Penghasilan dari pekerjaan seperti itu berupa gaji, upah, ataupun honorarium. Yang demikian itu apabila sudah mencapai nisabnya dan haulnya pendapatan yang ia hasilkan harus di keluarkan zakatnya.

2. Zakat profesi dalam perspektif UU No. 23 Tahun 2011 tentang pengelolaan zakat, memberi penegasan bahwa zakat profesi telah resmi dan sah terlembagakan secara formal, mengikat dan yuridis dalam regulasi Negara Indonesia. Termaktubnya zakat profesi dalam regulasi ini, disamping untuk memberi kepastian hukum pada individu yang Islam dan badan usaha yang dimiliki oleh orang Islam dalam transfer zakatnya kepada mustahiq juga dapat dijadikan sebagai bagian filantropi Islam yang dapat digunakan untuk kesejahtraan umat Islam dan umat yang lainnya, yang hal demikian ini merupakan juga bagian dari asas pengelolaan zakat perpspektif UU No. 23 Tahun 2011 tersebut.

\section{B. Saran}

Sebagai bentuk ibadah wajib, maka seharusnya umat Islam menyadari betul arti penting zakat. Islam yang rahmatul lillalamin sangat memperhatikan kesejahteraan umat. Dikarenakan pentingnya zakat profesi untuk pendistribusian pendapatan maka sebaiknya zakat profesi langsung diambil/dipotong dari setiap gaji, upah atau honorarium seorang muslim. 


\section{DAFTAR PUSTAKA}

Baidowi, Ikbal, 'ZAKAT PROFESI (ZAKAT PENGHASILAN)', TAZKIYA Jurnal Keislaman, Kemasyarakatan \& Kebudayaan, 19.1 (2018), 40-54

Marimin, Agus dan Tira Nur Fitria, 'Zakat Profesi (Zakat Penghasilan) Menurut Hukum Islam', Jurnal Ilmiah Ekonomi Islam, 01.01 (2015), 50-60

Pakpahan, Elpianti Sahara, 'PANDANGAN ULAMA TENTANG ZAKAT PROFESI', AL-HADI, III.2 (2018), 629-37

Riyadi, Fuad, 'Kontroversi Zakat Profesi Pesrpektif Ulama Kontemporer', Jurnal Zakat Dan Wakaf, 2.1 (2015), 110-12

Setiawan, Deny, 'ZAKAT PROFESI DALAM PANDANGAN ISLAM', JURNAL SOSIAL EKONOMI PEMBANGUNAN, 1.2 (2011), 195-208

Sholikah, Muhammad Aziz dan, 'UNDANG-UNDANG NO . 23 TAHUN 2011 DAN HUKUM ISLAM', Ulul Albab, 15.2 (2014), 188-205

Zen, Muhammad, 'Zakat Profesi Sebagai Distribusi Pendapatan Ekonomi Islam', Human Falah, 1.1 (2014), 63-91

Samsul, S. A. B. TUJUAN DAN SASARAN ZAKAT DALAM KONTEKS IBADAH DAN MUAMALAH

Putra, T. W. (2019). Penghimpunan Dana Zakat Infak Dan Sedekah di Badan Amil Zakat Nasional. Laa Maisyir: Jurnal Ekonomi Islam, 6(2), 246-260.

Putra, T. W. (2019). Manajemen Zakat pada Badan Amil Zakat Nasional Kota Makassar. JURNAL HUKUM EKONOMI SYARIAH, 2(2), 203-221.

Putra, T. W., Sofyan, A. S., \& Mongkito, A. W. (2020). Maqasid Zakat dalam Mengentaskan Kemiskinan. TASAMUH: Jurnal Studi Islam, 12(2), 355-372.

Setiawan, A., Putra, T. W., \& Hariyadi, R. (2020). Pembangunan Manusia melalui Optimalisasi Lembaga Pengelolaan Zakat. Management of Zakat and Waqf Journal (MAZAWA), 1(2), 79-91.

Ismawati, I., Sumarlin, S., Samsul, S., Sapa, N. B., \& Supriadi, S. (2020). SOSIALISASI PENTINGNYA ZAKAT DI LINGKUNGAN BONTOPARANG KELURAHAN BONTOKADATTO KECAMATAN POLONGBANGKENG SELATAN KABUPATEN TAKALAR SULAWESI SELATAN. ABDIMAS 
UNWAHAS, 5(1).

Putra, T. W. (2020). Struktur dan Pengendalian Internal Organisasi Pengelola Zakat. Madinah: Jurnal Studi Islam, 7(2), 151-166.

Setiawan, A., Putra, T. W., \& Hariyadi, R. (2020). ANALISIS KEBIJAKAN BAZNAS TENTANG IBNU SABIL SEBAGAI MUSTAHIK ZAKAT. Ar-Ribh: Jurnal Ekonomi Islam, 3(2). 